\title{
Palynostratigraphy of Permian succession from Binja Block, South Karanpura Coalfield, Jharkhand, India
}

\author{
Srikanta Murthy ${ }^{1, *}$, Archana Tripathi ${ }^{2, * *}$, B Chakraborti ${ }^{2}$ and U P Singh ${ }^{2}$ \\ ${ }^{1}$ Birbal Sahni Institute of Palaeobotany, Lucknow 226 007, India. \\ ${ }^{2}$ Geological Survey of India, Kolkata, India. \\ ${ }^{*}$ Corresponding author. e-mail: srikanta_murthy22@rediffmail.com
}

\begin{abstract}
Palynological investigations are carried out on approximately 538.00-m thick Gondwana strata from borehole SKB-1, Binja Block, South Karanpura Coalfield in Jharkhand. Based on the distribution pattern of age marker palynotaxa, two distinct palynoassemblages are identified. Palynoassemblage-I in the lithologically designated Barren Measures and Barakar formations, between 552.00 and $53.20 \mathrm{~m}$ depth show dominance of striate bisaccate (Striatopodocarpites, Crescentipollenites, and Faunipollenites) and abundance of nonstriate bisaccate (Scheuringipollenites). Upward the Palynoassemblage-II (39.50-13.80 $\mathrm{m}$ depth) is rich in striate bisaccate (Striatopodocarpites and Crescentipollenites) and significant enveloping monosaccate Densipollenites magnicorpus pollen. These strata have been equated with Raniganj Formation of Latest Permian age. The First Appearance Datum (FAD) of Arcuatipollenites pellucidus, Playfordiaspora cancellosa, Alisporites sp., Falcisporites sp. and Krempipollenites indicus observed at 13.80 and $39.50 \mathrm{~m}$ depth, mark the transition of Permian into the Lower Triassic. The FADs of Guttulapollenites spp. at 49.10 and $504.70 \mathrm{~m}$, Goubinispora morondavensis at $415.90 \mathrm{~m}$, Alisporites ovalis and Arcuatipollenites sp. at $526.70 \mathrm{~m}$ is observed and suggest that these sediments are equivalent to Raniganj Formation, Late Permian in age.
\end{abstract}

\section{Introduction}

South Karanpura Coalfield is located in the western part of the Damodar valley, situated between latitudes $23^{\circ} 38^{\prime}-23^{\circ} 45^{\prime} \mathrm{N}$ and longitudes $85^{\circ} 05^{\prime}-$ $85^{\circ} 28^{\prime} \mathrm{E}$ in the Ramgarh district of Jharkhand state. It covers an area of $194 \mathrm{~km}^{2}$ (figure 1). Palynological work has been done in this coalfield, namely by Bhattacharya et al. (1957); Khan (1962, 1964); Bharadwaj and Tiwari (1968); Bharadwaj and Anand Prakash (1972); Lele and Chandra (1977); Lele and Kulkarni (1969); Bharadwaj and Tripathi (1978); Bharadwaj and Dwivdi (1981) and Bandyopadhyay (1984). Most of the work is on the coal bearing Barakar Formation.
Binja Block of this coalfield is situated in the southwestern part of the South Karanpura Coalfield where the rocks of the Barren Measures and Raniganj formations are exposed on the surface (figure 1). The main objective of the present analysis is to determine the palynological dating of the borecore SKB-1 at Binja Block, South Karanpura Coalfield. The taphonomic study on the same material is also attempted to understand the depositional environment.

\section{General geology}

This east-west trending elongated coalfield, occurring within Damodar-Koel River Valley Basins is

Keywords. Palynostratigraphy; Permian; Raniganj Formation; Barren Measures; Barakar Formation; Binja Block; South Karanpura Coalfield.

\footnotetext{
** Deceased.

J. Earth Syst. Sci. 123, No. 8, December 2014, pp. 1895-1906

(C) Indian Academy of Sciences
} 


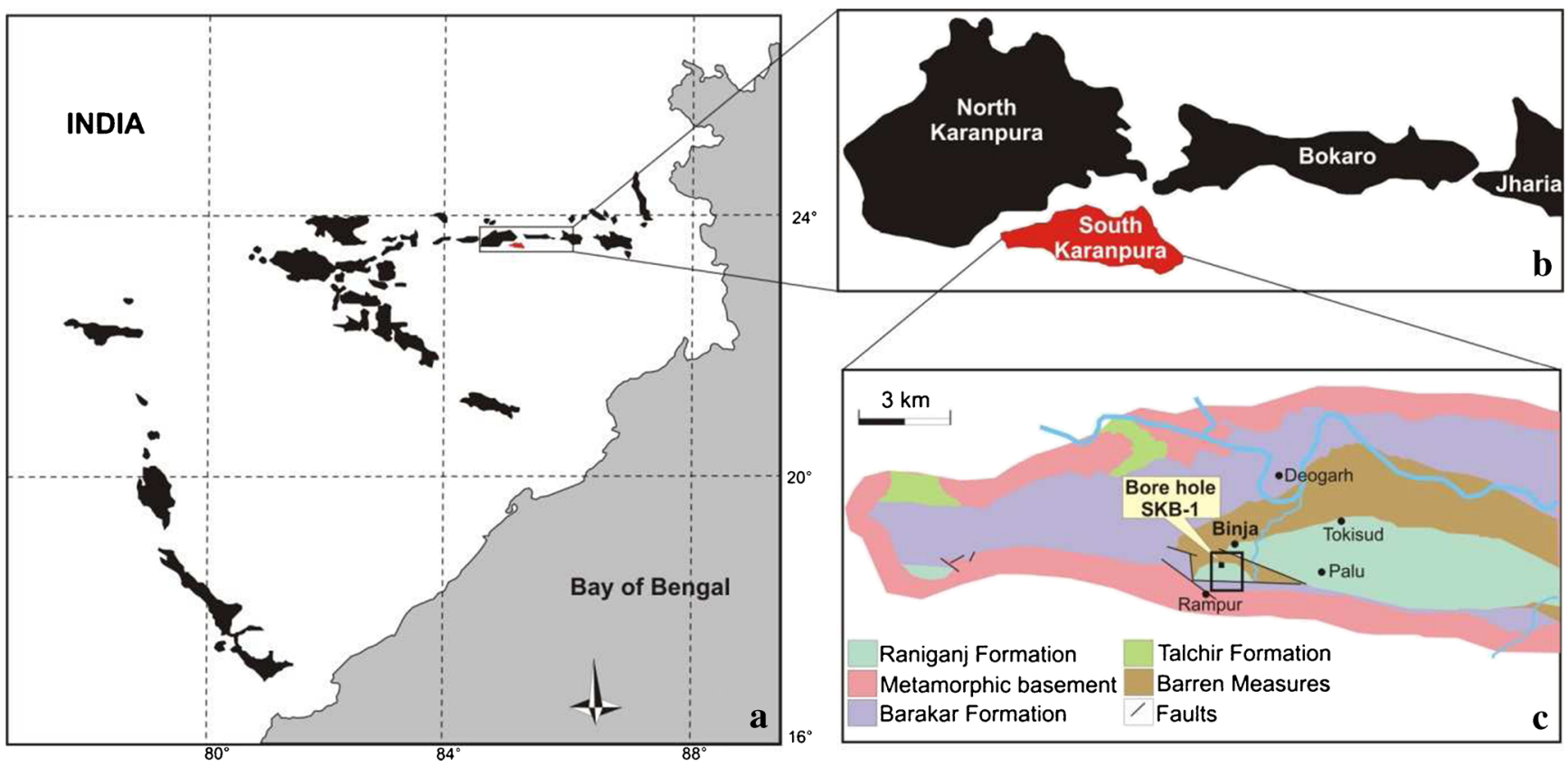

Figure 1. (a) Map showing coalfields in extrapeninsular India; (b) some coalfields in Damodar Koel River Valley, and (c) geologicalmap of South Karanpura Coalfield showing location of borehole SKB-1 (after Raja Rao 1987).

Table 1. General stratigraphic succession in South Karanpura Coalfield (modified after Raja Rao 1987).

Age

Formation

Lithology

Thickness range

Gondwana Supergroup

Lower Gondwana Group

Early Cretaceous Intrusive Lamprophyre and dolerite dykes and sills.

Late Permian $\quad$ Raniganj $\quad$ Fine-grained sandstones; grey, medium to coarse610 m

Late Permian $\quad$ grained, calcareous sandstones; grey shales (=mudstones); carb. shale; a few thin coal seams/bands.

Middle Permian

Barren MeasuresMedium grained sandstones; siltstones;

$304-457 \mathrm{~m}$ micaceous and carbonaceous shales;

(m) (approx.)

\section{Middle Permian}

Early Permian

Barakar

Early Permian

Early Permian to

Late Carboniferous ironstone shales.
Coarse grained sandstones, shales;
$1053 \mathrm{~m}$ about 42 economic coal seams.

Karharbari

Pebbly-to-coarse grained sandstones, shales and coal seams.

Talchir Olive green shales/green mudstones; fine to medium-grained sandstones; conglomerate; rhythmites and diamictites.

\section{b}

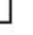




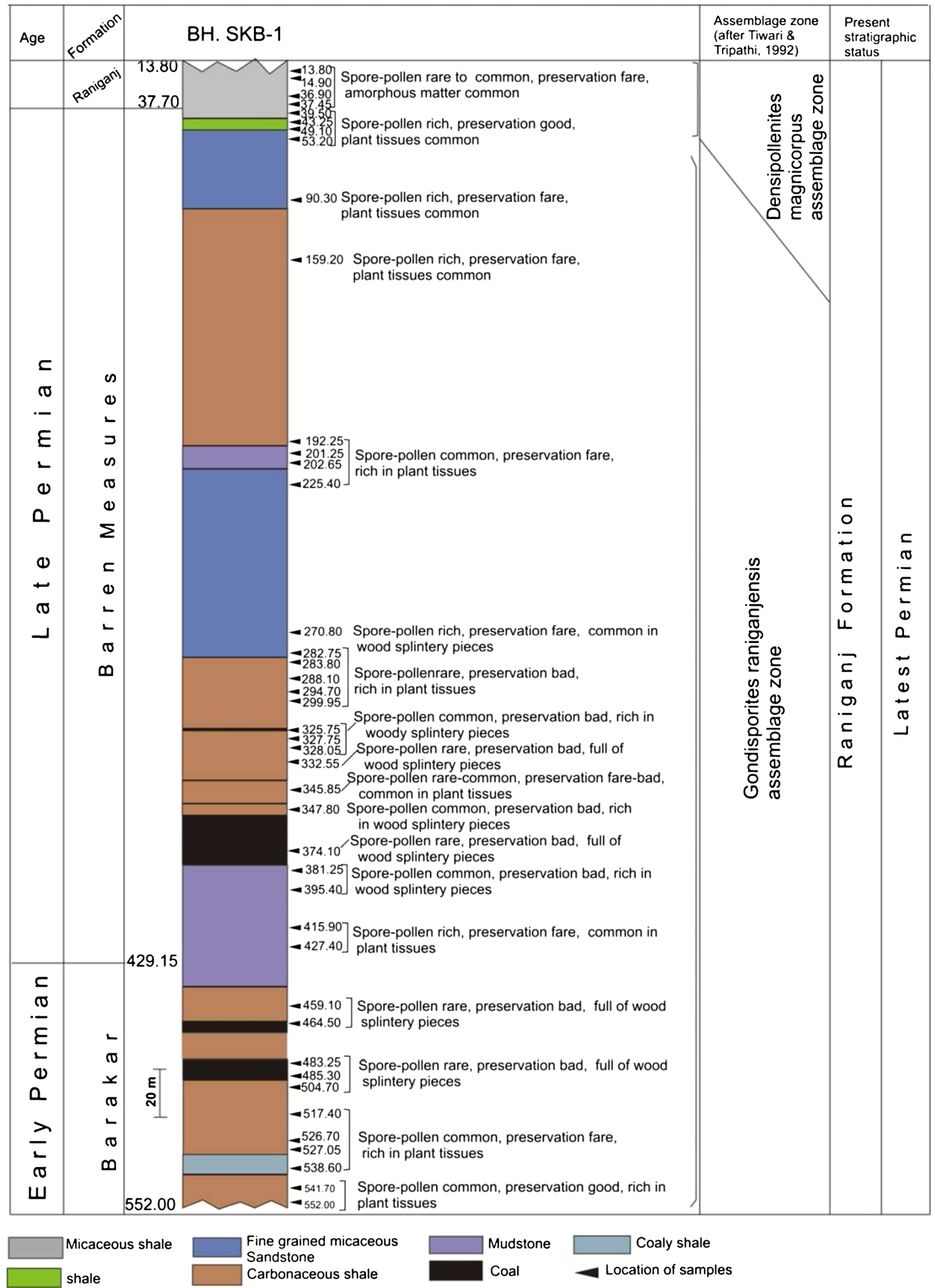

Figure 2. Lithocolumn in borehole SKB-1, to show different levels of occurrence of palynomorphs assemblage zone identified and their stratigraphic status. 
bounded by metamorphic basement rocks to the north and south. The rocks of the Talchir Formation are mostly exposed in patches in lenticular fashion in the fringe areas along the northern, southern, and eastern margins of the coalfield. A continuous succession from Talchir to Raniganj formations is preserved in this basin. Major parts of this basin are occupied by Barakar Formation,
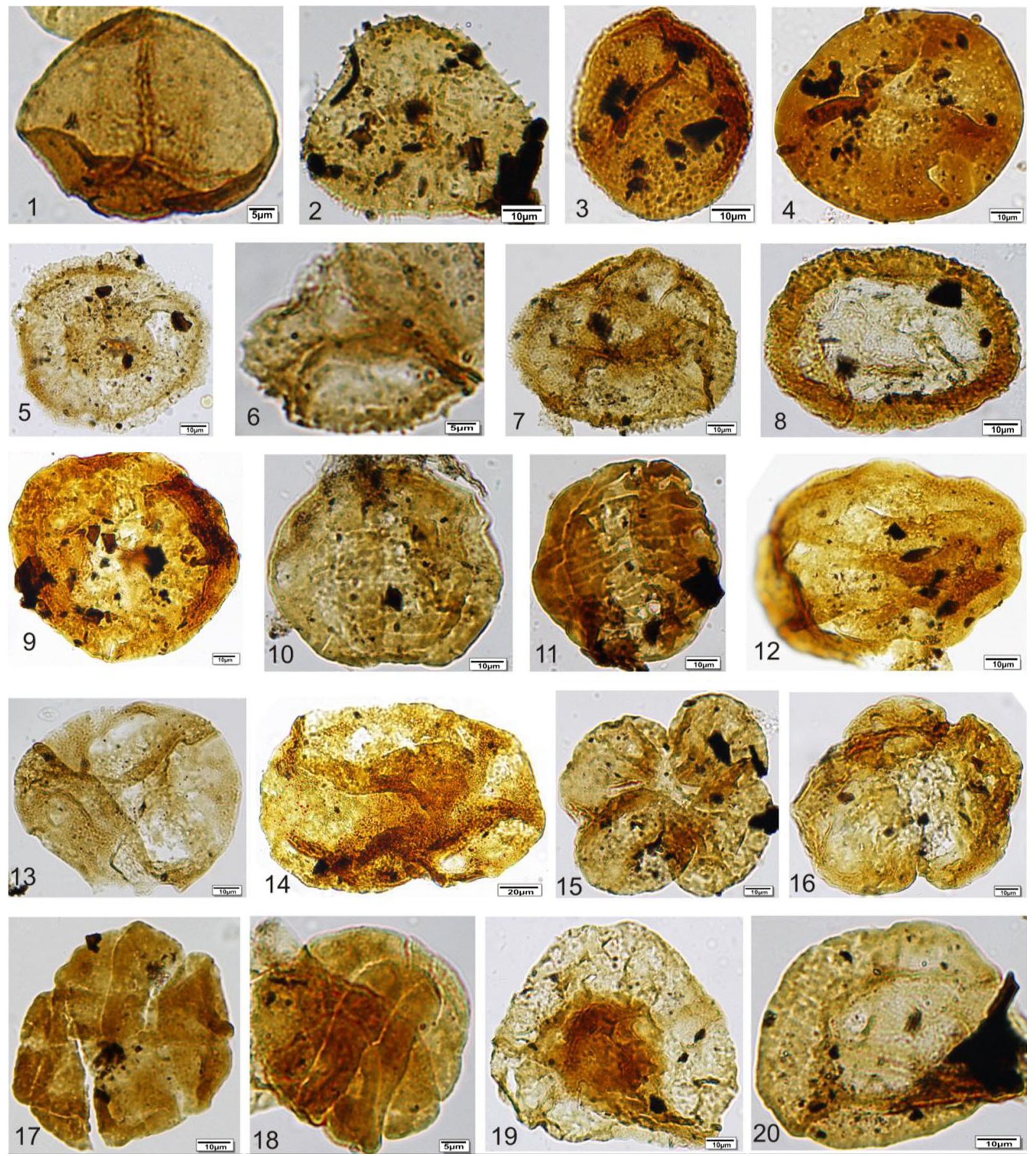

Plate I. 1. Cyclogranisporites triletes Kar (1970); 2. Horriditriletes curvibaculus Bharadwaj and Salujha (1964); 3. Microbaculispora tentula Tiwari (1965); 4. Microfoveolatispora foveolata Tiwari (1965); 5. Gondisporites reticulates Tiwari and Ram-Awatar (1988); 6. Indotriradites korbaensis Tiwari (1964); 7. Gondisporites sp.; 8. Parasaccites obscurus Tiwari (1965); 9. Barakarites crassus Bharadwaj and Tiwari (1964); 10. Striamonosaccites ovatus Bharadwaj (1962); 11. Distriasulcites ovatus Venkatachala and Kar (1968); 12. Densipollenites magnicorpus Tiwari and Rana (1981); 13. Densipollenites invisus Bharadwaj and Salujha (1964); 14. Densipollenites densus Bharadwaj and Srivastava (1969); 15. Goubinispora sp.; 16. Goubinispora morondavensis (Goubin) and Rana (1981); 17. Guttulapollenites gondwanensis Goubin (1965); 18. Guttulapollenites hannonicus Goubin (1965); 19. Playfordiaspora cancellosa Maheshwari and Banerji emend. Vijaya (1995); 20. Kamthisaccites kamthiensis Srivastava and Jha (1986). 

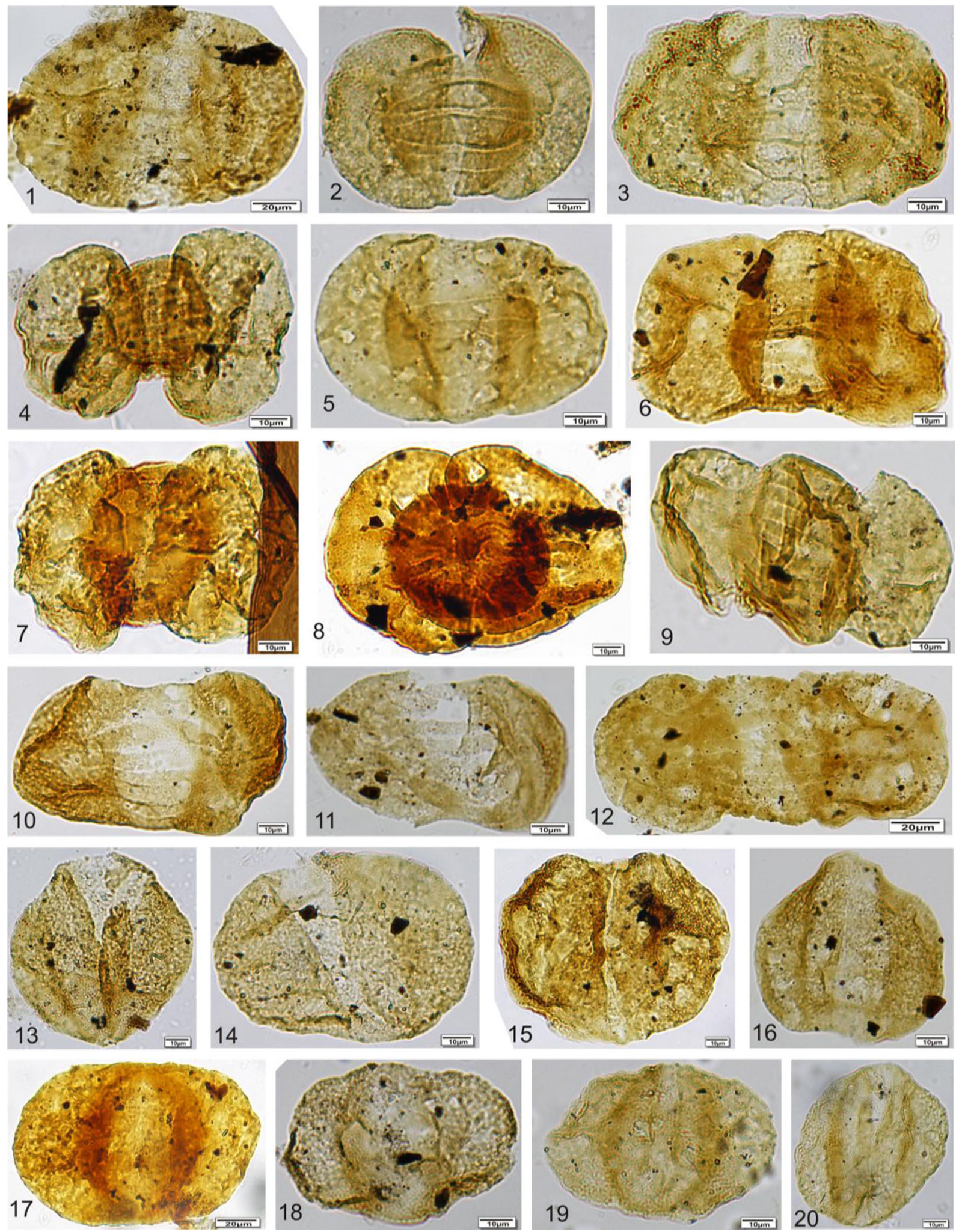

Plate II. 1. Faunipollenites varius Bharadwaj (1962); 2. Striatites varius Kar (1968); 3. Striatopodocarpites magnificus Bharadwaj and Salujha (1964); 4. Verticipollenites gibbosus Bharadwaj (1962); 5. Crescentipollenites fuscus (Bharadwaj) Bharadwaj, Tiwari and Kar (1974); 6. Crescentipollenites sp.; 7. Platysaccus densicorpus Anand-Prakash (1972); 8. Rhizamospora triassica Tiwari and Rana (1981); 9. Distriatites bilateris Bharadwaj (1962); 10. Arcuatipollenites pellucidus (Goubin) Tiwari and Vijaya (1995); 11. Arcuatipollenites sp.; 12. Arcuatipollenites damudicus (Tiwari and Rana) Tiwari and Vijaya (1995); 13. Scheuringipollenites tentulus Tiwari (1973); 14. Scheuringipollenites barakarensis Tiwari (1973); 15. Scheuringipollenites maximus Tiwari (1973); 16. Krempipollenites sp.; 17. Alisporites ovalis Kumar (1973); 18. Alisporites sp.; 19. Satsangisaccites nidpurensis Bharadwaj and Srivastava 1969; 20. Krempipollenites indicus Tiwari and Vijaya (1995). 
which lies unconformably over the basement in large areas. To the east and northeast, Barakar Formation conformably overlies the older rocks whereas in the southern parts, it is faulted against the basement. In totality, this coalfield contains 42 regional Barakar coal seams within a thick pile of lower coal measure, though not all the seams are developed in any single block. The outcrops of Barren Measures and Raniganj are exposed at the central part (Raja Rao 1987).

Lamprophyre and dolerite dykes and sills are reported to occur at different stratigraphic levels within the Barakar, Barren Measures, and Raniganj formations.

Based on available literatures and unpublished Progress Reports of GSI, the generalized stratigraphic succession in the South Karanpura Coalfield (modified after Raja Rao 1987) is given in table 1 .

\section{Materials and methods}

The study is based on the material from bore core SKB-1, total depth in the borecore is approximately $538.00 \mathrm{~m}(13.80-552.00 \mathrm{~m})$. The borecore intersected through Raniganj, Barren Measures, and Barakar formations. The formational contactRaniganj/Barren Measures is marked at $37.70 \mathrm{~m}$ and Barren Measures/Barakar at $429.15 \mathrm{~m}$ (table 2 and figure 2). In all 73 rock samples that were collected for palynological study, 42 samples yielded palynomorphs. Sediments are processed by standard maceration technique. For each sample, $50 \mathrm{gm}$ of sediments were taken and crushed, were first treated with $40 \%$ hydrofluoric acid for 3-4 days to remove silica material, and then followed by nitric acid for 5 days for digestion of humic matter. Then they were treated with $10 \%$ potassium hydroxide to release the humus. The maceral were mounted in polyvinyl alcohol and Canada balsam. Five slides from each sample were prepared and pollen-spores were observed under the transmitted light microscope.

\section{Palynological observation}

Borehole SKB-1 (13.80-552.00 m depth) from Binja Block of South Karanpura Coalfield has been worked out for the dating of the intersected strata. The samples comprise diverse lithofacies and recovery of spores and pollen is average and varies from poor to fair (Plates I and II). Besides, an abundance of wood shreds, plant tissues and organic matter were also observed. For details, see figure 2.

The overall composition of spore-pollen, i.e., diversity in their relative abundances along with the presence of significant age marker taxa (tables 3 and 4) at different depth intervals in the borehole SKB-1 are discussed here. Here two palynoassemblages are identified (figure 2 and table 3 ).

\subsection{Palynoassemblage-I}

Depth: 552.00-53.20 m; carbonaceous shales, micaceous shales, mudstones, fine-to-medium grained sandstones with charcoal, coaly shales, and coals (figure 2 and table 3 ).

In the strata between 53.20 and $552.00 \mathrm{~m}$ depth in borehole SKB-1 the assemblage contains dominance of species of Striatopodocarpites followed by Crescentipollenites, Faunipollenites and Scheurin-

Table 3. Palynodating in Borehole SKB-1 (13.80-552.00 m depth), South Karanpura Coalfield.

\begin{tabular}{|c|c|c|c|c|c|}
\hline \multirow{2}{*}{$\begin{array}{l}\text { Lithostratigraphic } \\
\text { formation }\end{array}$} & \multirow{2}{*}{$\begin{array}{l}\text { Assemblage } \\
\text { identified }\end{array}$} & \multirow{2}{*}{$\begin{array}{l}\text { Placement in } \\
\text { Palynozone } \\
\text { (Tiwari and } \\
\text { Tripathi 1992) }\end{array}$} & \multicolumn{2}{|c|}{ Present stratigraphic status } & \multirow[b]{2}{*}{ Remarks } \\
\hline & & & Formation & Age & \\
\hline $\begin{array}{l}\text { Raniganj } 13.80 \\
-37.70 \mathrm{~m}-\end{array}$ & $\begin{array}{l}\text { Palynoassemblage-II } \\
(13.80-39.50 \mathrm{~m})\end{array}$ & $\begin{array}{l}\text { Densipollenites } \\
\text { magnicorpus }\end{array}$ & Raniganj & Late Permian & $\begin{array}{l}\text { Equivalent } \\
\text { to Raniganj } \\
\text { Formation }\end{array}$ \\
\hline \multirow[t]{2}{*}{$\begin{array}{l}\text { Barren Measures } \\
-429.15 \mathrm{~m}-\end{array}$} & & $\hat{\uparrow}$ & & $\uparrow$ & \\
\hline & $\begin{array}{l}\text { Palynoassemblage-I } \\
(53.20-552.00 \mathrm{~m})\end{array}$ & $\begin{array}{l}\text { Gondisporites } \\
\text { raniganjensis }\end{array}$ & Raniganj & Late Permian & \\
\hline $\begin{array}{l}\text { Barakar } \\
552.00 \mathrm{~m}\end{array}$ & & $\downarrow$ & & $\downarrow$ & \\
\hline
\end{tabular}


Table 4. List of spore-pollen species identified in Borehole SKB-1, South Karanpura Coalfield.

\section{Simple Trilete Spore}

Brevitriletes unicus Bharadwaj and Srivastava emend.

Tiwari and Singh (1981)

Callumispora barakarensis Bharadwaj and Srivastava emend. Tiwari et al. (1989)

Cyclogranisporites gondwanentis Bharadwaj and Salujha (1964)

Cyclogranisporites triletes Kar (1970)

Cyclogranisporites sp.

Cyclobaculisporites minutus Bharadwaj and Salujha (1964)

Cyclobaculisporites indicus Bharadwaj and Salujha (1964)

Cyclobaculisporites sp.

Didecitriletes horridus Venkatachala and Kar emend.

Tiwari and Singh (1981)

Horriditriletes curvibaculosus Tiwari (1965)

Microbaculispora barakasrensis Tiwari emend.

Tiwari and Singh (1981)

Microbaculispora gondwanensis Bharadwaj (1962)

Microbaculispora tentula Tiwari (1965)

Microfoveolatispora foveolata Tiwari (1965)

Microfoveolatispora bokaroensis Tiwari (1965)

Zonate Trilete Spores

Gondisporites reticulatus Tiwari and Ram-Awatar (1988)

Gondisporites raniganjensis Bharadwaj (1962)

Gondisporites sp.

Indotriradites korbaensis Tiwari (1964)

Monosaccate Pollen

Parasaccites obscures Tiwari (1965)

Bharadwajiapollis striatus Kar (1969)

Barakarites indicus Bharadwaj and Tiwari (1964)

Barakarites crassus Bharadwaj and Tiwari (1964)

Densipollenites densus Bharadwaj and Srivastava (1969)

Densipollenites invisus Bharadwaj and Salujha (1964)

Densipollenites magnicorpus Tiwari and Rana (1980)

Densipollenites indicus Bharadwaj (1969)

Parasaccites bilateralis Bharadwaj and Tiwari (1964)

Striomonosaccites ovatus Bharadwaj (1962)

Playfordiaspora cancellosa Maheshwari and Banerji emend. Vijaya (1995)

Kamthisaccites kamthiensis Srivastava and Jha (1986)

Goubinispora morondavensis (Goubin) Tiwari

and Rana (1981)

Goubinispora morondavensis sp.

Nonstriate Bisaccate Pollen

Platysaccus densus Kar (1968)

Platysaccus ovatus Maithy (1965)

Platysaccus densicorpus Anand Prakash (1972)

Scheuringipollenites maximus (Hart) Tiwari (1973)

Scheuringipollenites tentulus (Tiwari) Tiwari (1973)

Scheuringipollenites barakarensis (Tiwari) Tiwari (1973)
Table 4. (Continued.)

Alisporites ovalis Kumar (1973)

Alisporites sp.

Krempipollenites indicus Tiwari and Vijaya (1995)

Krempipollenites sp.

Satsangisaccites nidpurensis Bharadwaj and

Srivastava (1969)

Striate Bisaccate Pollen

Crescentipollenites gondwanensis (Maheshwari)

Bharadwaj et al. (1974)

Crescentipollenites fuscus Bharadwaj,

Tiwari and Kar (1974)

Crescentipollenites sp.

Distriatites bilateris Bharadwaj (1962)

Distriamonocolpites ovalis Bharadwaj and Sinha (1969)

Distriasulcites ovatus Venkatachala and Kar (1968)

Faunipollenites singrauliensis Sinha (1972)

Faunipollenites varius Bharadwaj emend.

Tiwari et al. (1989)

Rhizomaspora indica Tiwari (1965)

Rhizomaspora triassica Tiwari and Vijaya Rana (1981)

Rhizomaspora radiata Wilson (1965)

Striasulcites ovatus Venkatachala and Kar (1968)

Striasulcites tectus Venkatachala and Kar (1968)

Striatites communis Bharadwaj and Salujha (1964)

Striatites reticuloidus Tiwari (1965)

Striatites notus Bharadwaj and Salujha (1964)

Striatites rhombicus Bharadwaj and Salujha (1964)

Striatites gopalensis Srivastava (1970)

Striatites varius Kar (1968)

Striatopodocarpites magnificus

Bharadwaj and Salujha (1964)

Striatopodocarpites ovatus (Maheshwari) Bharadwaj and Archana Dwivedi (1981)

Striatopodocarpites diffusus Bharadwaj and Salujha (1964)

Tiwariasporis gondwanensis (Tiwari) Maheswari and Kar (1967)

Verticipollenites gibbosus Bharadwaj (1962)

Verticipollenites oblongus Bharadwaj (1962)

Taeniate

Guttulapollenites hannonicus Goubin (1965)

Guttulapollenites gondwanensis Goubin (1965)

Guttulapollenites sp.

Arcuatipollenites ovatus Tiwari and Vijaya (1995)

Arcuatipollenites pellucidus (Goubin) Tiwari and Vijaya (1995)

Arcuatipollenites damudicus (Tiwari and Rana)

Tiwari and Vijaya (1995)

Arcuatipollenites sp.

Sulcate

Weylandites indicus Bharadwaj and Srivastava (1969) 


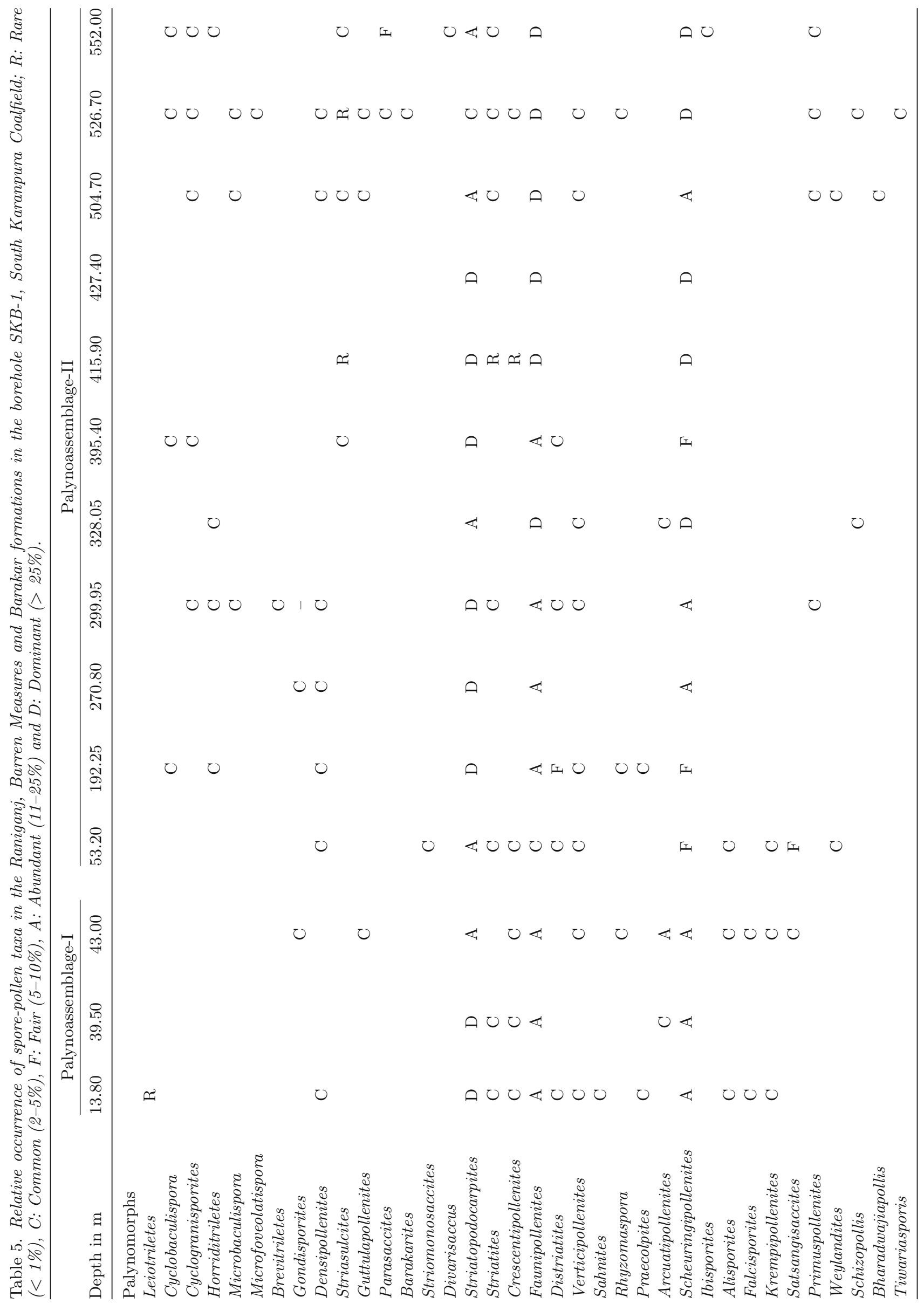




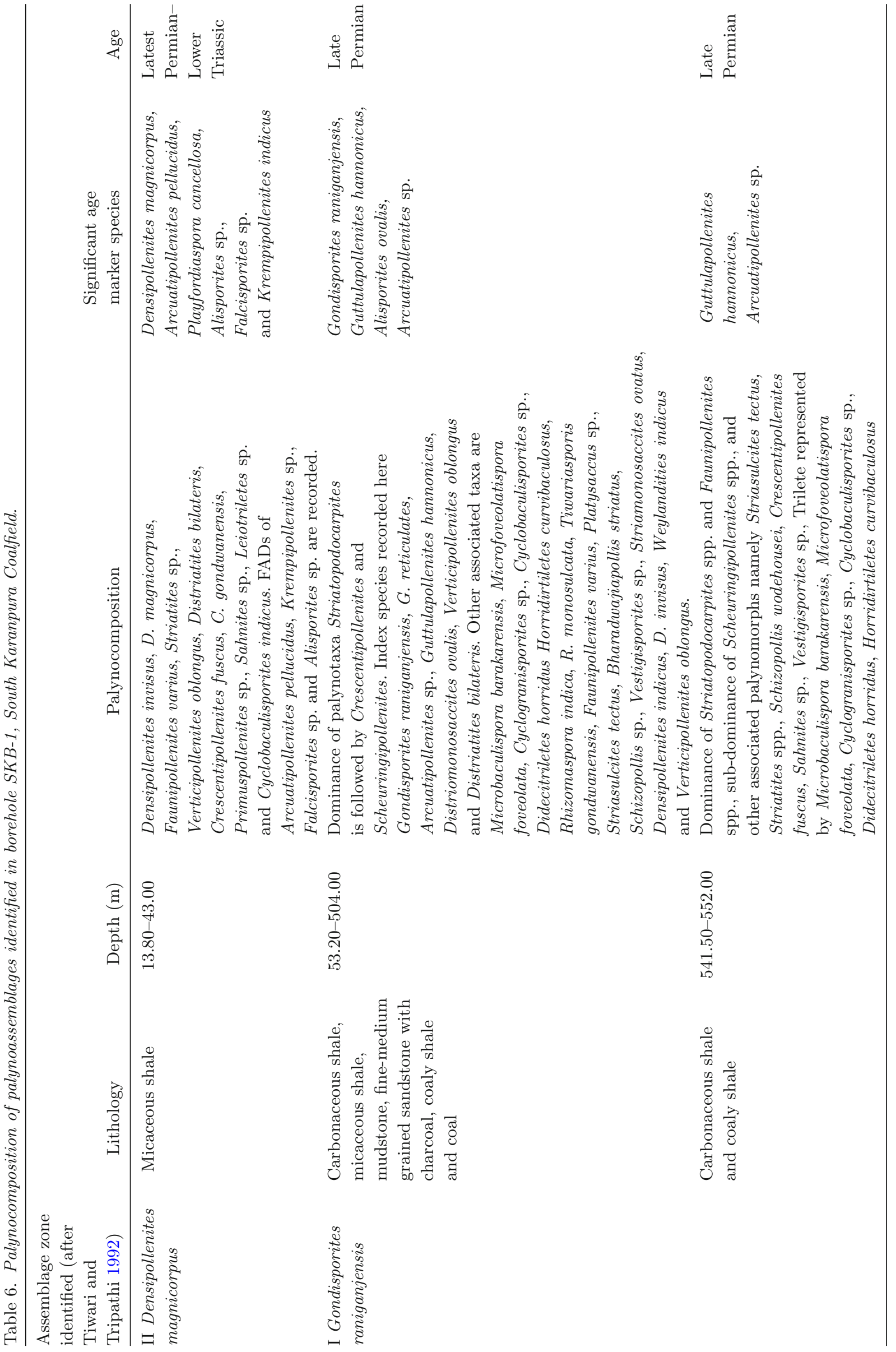


gipollenites genera. Characteristic age marker species recovered in this assemblage are Gondisporites raniganjensis, $G$. reticulates, Guttulapollenites hannonicus, Distriomonosaccites ovalis, Verticipollenites oblongus and Distriatites bilateris. Other associated taxa are Microbaculispora barakarensis, Microfoveolatispora foveolata, Cyclogranisporites sp., Cyclobaculisporites sp., Didecitriletes horridus, Horridirtiletes curvibaculosus, Tiwarisporis gondwanensis, Rhizomaspora indica, $R$. monosulcata, Faunipollenites varius, Platysaccus sp., Striasulcites tectus, Bharadwajiapollis striatus, Schizopollis sp., Vestigisporites sp., Striomonosaccites ovatus, Densipollenites indicus, D. invisus, Weylandities indicus and Verticipollenites oblongus.

Remarks: By the significant quantitative presentation of Gondisporites raniganjensis, G. reticulatus in the population of striate bisaccate pollen taxa, this assemblage is comparable to the Gondisporites raniganjensis, established in the Raniganj Formation of the Damodar Basin (Tiwari and Tripathi 1992) which is dated as Late Permian in age.

\subsection{Palynoassemblage-II}

Depth: $39.50-13.80 \mathrm{~m}$; siltstones, micaceous shales, and mudstones (figure 2 and table 3).

Palynoassemblage recovered in the interval of 13.80-39.50 $\mathrm{m}$ depth in borehole SKB-1 shows dominance of striated bisaccate pollen Striatopodocarpites spp. with increased frequency of enveloping monosaccate pollen Densipollenites ( $D$. invisus and D. magnicorpus). The palynoassemblage is much diversified in having abundant striate bisaccate pollen - Faunipollenites varius, Striatites sp., Verticipollenites oblongus, Distriatites bilateris, Crescentipollenites fuscus, $C$. gondwanensis, Primuspollenites sp. and Sahnites sp. The trilete spores are very rare and represented by Leiotriletes sp. and Cyclobaculisporites indicus. FADs of Arcuatipollenites pellucidus, Krempipollenites sp., Falcisporites sp., and Alisporites sp. are recorded in this interval.

Remarks: Palynoassemblage-II, compares with the Densipollenites magnicorpus palynoassemblage

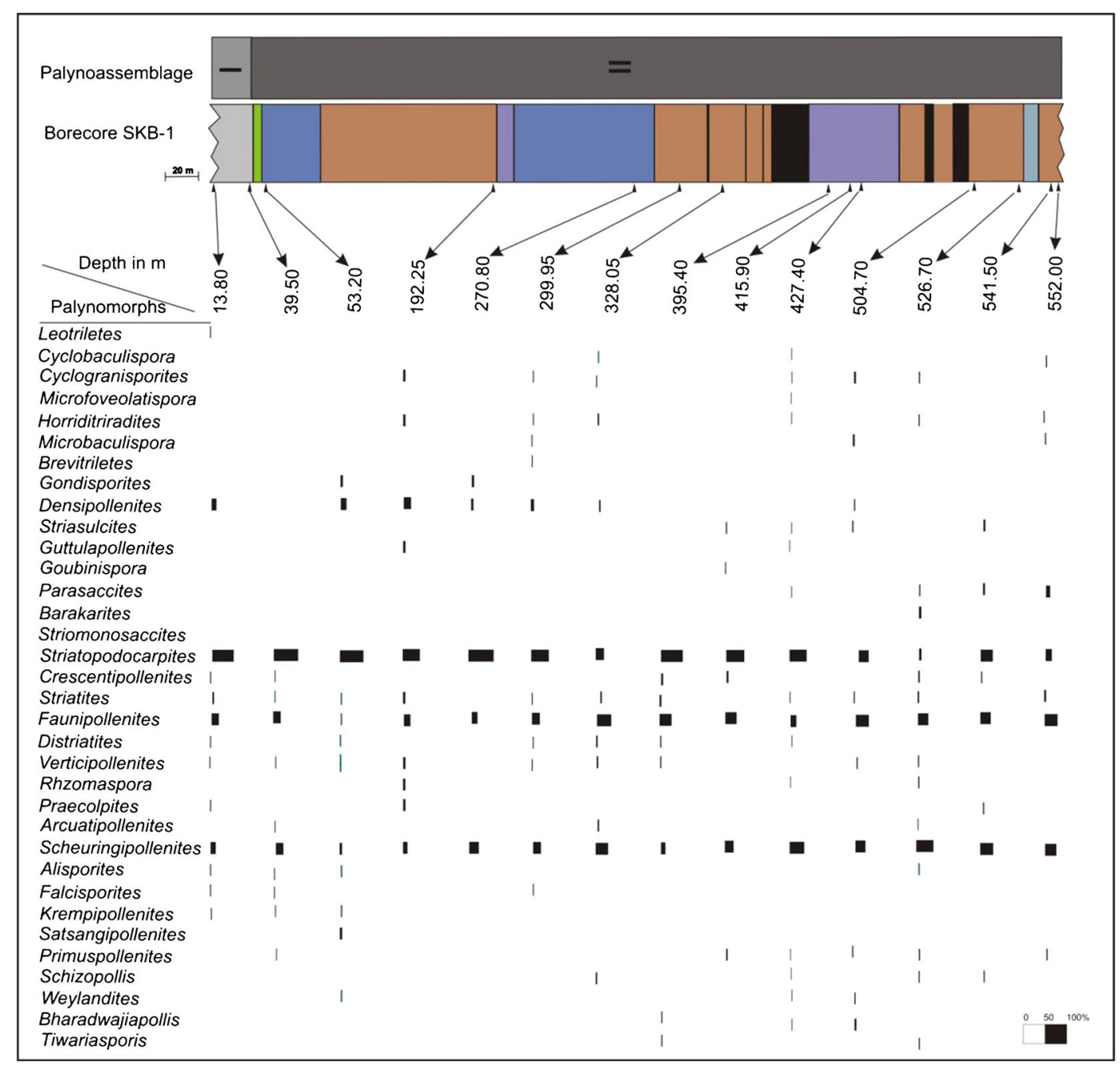

Figure 3. Distribution of important palynotaxa in the borecore SKB-1, South Karanpura Coalfield. 
of Tiwari and Tripathi (1992) in having relatively fair occurrence of $D$. magnicorpus and this composition suggests the Latest Permian in age. The FADs of Arcuatipollenites pellucidus, Playfordiaspora cancellosa, Krempipollenites indicus, Falcisporites sp., and Alisporites sp. observed at 13.80, 14.90 and $39.50 \mathrm{~m}$ depths mark the transition from Permian to Triassic period.

\section{Discussion}

The recovery of palynomorphs in approximately $538.00 \mathrm{~m}(13.80-552.00 \mathrm{~m})$ thick Gondwana strata is observed with both palynomorphs and palynodebris in equal proportion (figure 2). The palynodebris consists of lumps of organic matter and plant tissues that includes dark to brown woody splinters, amorphous matter (figure 2). This infers high energy flow regime during the deposition of the present studied material. Lithologically the formation intersected in the borecore are Raniganj, Barren Measures, and Barakar formations. The formational contacts - Raniganj and Barren Measures formations is delimited at $37.70 \mathrm{~m}$ depth, and Barren Measures and Barakar formations at $429.15 \mathrm{~m}$ depth (table 2). The palynological investigation reveals presence of two palynoassemblages. The vertical placement of the two palynoassamblages (I-II) identified, is based upon the stratigraphical importance of the age marker taxa and their relative occurrences along with other associated significant marker species (tables 3, 5, 6, and figure 3 ). On the basis of the standard palynozonation schemes established for the Permian successions in India (Tiwari and Tripathi 1992), the identified palynoassemblages are used to date the studied litho-succession in borehole SKB-1.

The palynoassemblage-I recorded in strata between 552.00 and $53.20 \mathrm{~m}$ depth in borehole is lithologically delimited as Raniganj, Barren Measures, and Barakar formations, contain a prolific palynoassemblage of striate bisaccate pollen taxa with fair presence of Gondisporites raniganjensis, G. reticulates and Densipollenites magnicorpus at 192.25 and $270.80 \mathrm{~m}$ depth and FADs of Guttulapollenites spp. at 415.90, 504.70, and $526.70 \mathrm{~m}$; Goubinospora sp. at $415.90 \mathrm{~m}$; Alisporites ovalis, and Arcuatipollenites sp. are at $552.00 \mathrm{~m}$ depth. This kind of composition correlates with Gondisporites raniganjensis palynoassemblage of Raniganj Formation, Damodar Basin which was considered Late Permian by Tiwari and Tripathi (1992).

In palynoassemblage-II, the significant record of enveloping monosaccate pollen Densipollenites and striate bisaccate pollen Stiatopodocarpites and Crescentipollenites, between 13.80 and $39.50 \mathrm{~m}$ depth, corroborate this part with the Raniganj Formation of Latest Permian age (Tiwari and Tripathi 1992). FADs of Early Triassic palynomorphs, viz., Arcuatipollenites pellucidus, Playfordiaspora cancellosa, Krempipollenites indicus, Alisporites sp., and Falcisporites sp. mark these sediments to span Permian to Early Triassic transition.

\section{Conclusion}

The palynological study done in approximately $538.00 \mathrm{~m}$ thick Gondwana strata in the Borehole SKB-1, South Karanpura Coalfield revealed that:

- The strata between 552.00 and $53.20 \mathrm{~m}$ depths are lithologically identified as Barren Measures and Barakar formations. The palynoassemblage here contain an abundance of Striatopodocarpites spp., Crescentipollenites sp., Faunipollenites varius, Densipollenites magnicorpus, Gondipollenites raniganjensis, and Scheuringipollenites spp. The FAD of Guttulapollenites hannonicus at $504.00,526.70 \mathrm{~m}$ are observed. This composition compares well with the Raniganj Formation of Late Permian in age.

- Lithological strata between 39.50 and $13.80 \mathrm{~m}$ depths are of Raniganj Formation. Palynological dating also indicates Latest Permian age by the presence of stratigraphic age marker species Densipollenites magnicorpus. The occurrence of Early Triassic palynomorphs like Arcuatipollenites pellucidus, Playfordiaspora cancellosa, Krempipollenites sp., Falcisporites sp., and Alisporites sp., suggest that these strata mark the transition from Permian into Lower Triassic period.

- The FAD of Arcuatipollenites pellucidus at 13.00, 39.50, $552.00 \mathrm{~m}$; Playfordiaspora cancellosa at 13.00, $39.50 \mathrm{~m}$; Gondisporites raniganjensis, $G$. reticulates, and Densipollenites magnicorpus at 13.00, 43.00, 192.25, and $270.80 \mathrm{~m}$ and Guttulapollenites spp. at $415.90,504.70$ and $526.70 \mathrm{~m}$; and Goubinispora sp. at $415.90 \mathrm{~m}$ depth records the Late Permian (Raniganj Formation) age for the complete succession of the borehole SKB-1.

- The complete strata of borecore SKB-1 is dated as Late Permian in age.

\section{Acknowledgements}

Authors (Archana Tripathi and S Murthy) are thankful to Director, BSIP, Lucknow for kindpermission to publish this work. They extend their sincere thanks to the Deputy Director General and officers of the Coal Wing Division, Geological Survey of India, Kolkata, for providing 
borecore samples for the present palynological study. This work has been carried out under MOU between BSIP and Coal Wing Division, Geological Survey of India, Kolkata. Authors also extend sincere thanks to reviewer Dr Ana M Zavattiieri for critical suggestions and comments, which have greatly improved the earlier version of the manuscript.

\section{References}

Bandyopadhyay N N 1984 A reappraisal of microfloral assemblage from Barakar stage of South Karanpura Coalfield, Bihar with remarks on the age of the coal beds; In: Symp. Evolutionary Bot. \& Biostratigraphy, Calcutta (1979) (eds) Sharma A K et al., pp. 303-314.

Bharadwaj D C and Prakash Anand 1972 On the palynostratigraphy of Argada S Seam, South Karanpura Coalfield, Bihar; Palaeobotanist 19(1) 211-213.

Bharadwaj D C and Dwivdi A 1981 Spore dispersae from the Barakar sediments from South Karanpura Coalfield, Bihar, India; Palaeobotanist 27 21-94.

Bharadwaj D C and Tiwari R S 1968 Sporological correlation of coal seams in Saunda and Gidi area of South Karanpura Coalfield, Bihar; Palaeobotanist 16(1) 38-55.
Bharadwaj D C and Tripathi A 1978 A palynostratigraphic study of Lower Gondwana sediments from South Karanpura Coalfield, Bihar, India; Palaeobotanist 25 39-61.

Bhattacharya D, Ray Chudhury T and Dutta K 1957 On fossil spores and pollen from the Lower Gondwanas of the Raniganj and South Karan coalfields; Quart. JI. Geol. Minearal. Metall. Soc. India 29(1) 51-52.

Khan A M 1962 Palynological study of drill cores from B.H.K. Su 47, South Karanpura Coalfield, Bihar; Indian Mineral. 16(3) 307.

Khan A M 1964 A note on trilete, monolete, monocolpate miospore from the Barakar coals, South Karanpura Coalfield; Indian Mineral. 18(1) 93.

Lele K M and Chandra M 1977 Association of Mio and Megafloras in the roof shales of some Barakar coal seams, South Karanpura Coalfield, Bihar; Palaeobotanist 24(3) 254-260.

Lele K M and Kulkarni S 1969 Two miospore assemblages from the Argada Sector, South Karanpura Coalfield, Bihar, with remarks on the probable age; Palaeobotanist 17(3) 288-294.

Raja Rao C S 1987 Coalfields of India; Bull. Geol. Surv. India $A-I V$ 45(I) 60.

Tiwari R S and Tripathi A 1992 Marker assemblage zones of spore and pollen species through Gondwana Palaeozoic and Mesozoic sequence in India; Palaeobotanist 40194 236. 